\title{
Deteksi Dini dan Edukasi Gangguan Pertumbuhan dan Perkembangan Pada Balita di Desa Podomoro Kabupaten Pringsewu
}

\author{
Dzul Istiqomah Hasyim $^{1 *}$, Nurwinda Saputri ${ }^{2}$ \\ ${ }^{1,2}$ Fakultas Kesehatan Universitas Muhammadiyah Pringsewu \\ dzulistiqomah10@umpri.ac.id
}

\begin{abstract}
Abstrak : Deteksi Dini dan Edukasi Gangguan Pertumbuhan dan Perkembangan Pada Balita di Desa Podomoro Kabupaten Pringsewu. Penting untuk dipahami bahwa dengan skrining dan mengetahui adanya masalah pada perkembangan anak, tidak berarti bahwa diagnosa pasti dari kelalaian tersebut telah ditetapkan. Skrining hanyalah prosedur rutin dalam pemeriksaan tumbuh kembang anak sehari-hari, yang dapat memberikan petunjuk jika ada sesuatu yang perlu mendapat perhatian. Sehingga masih diperlukan anamnese yang baik, pemeriksaan fisik yang teliti dan pemeriksaan penunjang lainnya agar diagnosa dapat dibuat, supaya intervensi dan pengobatan dapat dilakukan sebaik-baiknya. Tujuan dari pengabdian ini adalah untuk mendeteksi dini gangguan pertumbuhan dan perkembangan pada usia balita serta memberikan edukasi kepada orangtua pentingnya secara rutin untuk memeriksakan pertumbuhan dan perkembangan anaknya serta stimulasi-stimulasi yang harus diberikan dan faktor yang mempengaruhi. Sasaran kegiatan ini adalah orangtua dan balita yang berusia 2-54 bulan. Metode yang digunakan dalam kegiatan adalah instrument deteksi tumbuh kembang anak KPSP dan untuk meningkatkan pengetahuan orang tua tentang tumbuh kembang dilakukan dengan penyuluhan, diskusi tanya jawab dan demonstrasi cara stimulasi tumbuh kembang anak. Hasil deteksi dini penilaian pertumbuhan dengan kurva WHO didapatkan sebanyak 38 anak (92\%) perawakan normal dan gizi normal dan 2 anak (8\%) yaitu gizi kurang. Untuk pemeriksaan perkembangan anak dengan instrument KPSP didapatkan hasil sebanyak 35 anak (95\%), dengan perkembangan sesuai. dan 5 anak (5\%) dengan perkembangan meragukan.Edukasi yang diberikan pada orangtua menunjukkan peserta aktif dalam kegiatan diskusi tanya jawab dan demonstrasi stiimulasi tumbuh kembang.
\end{abstract}

Kata Kunci : Tumbuh Kembang balita

\section{PENDAHULUAN}

Menurut (World Health Organization) WHO masalah tumbuh kembang anak merupakan masalah yang perlu diketahui atau dipahami sejak konsepsi hingga dewasa (Hidayat, 2009). Pembinaan tumbuh kembang anak secara komprehensif dan berkualitas diselenggarakan melalui kegiatan stimulasi, deteksi dan intervensi dini pemyimpangan tumbuh kembang balita dilakukan mulai "masa kritis". Stimulasi deteksi bisa melalui Kuesioner Pra Skrining Perkembangan (KPSP), adalah kegiatan merangsang kemampuan dasar anak umur 0-54 bulan agar anak tumbuh dan berkembang secara optimal. Kurangnya stimulasi dapat menyebabkan pemyimpangan tumbuh kembang anak bahkan gangguan yang menetap (Depkes, 2012)

Pertumbuhan ialah dimana bertambahnya ukuran fisik pada anak, baik tinggi badan maupun berat badan yang kaitannya dengan status gizi. Pertembahan lingkar kepala juga harus diperhatikan dan dipantau secara berkala karnahal ini berkaitan dengan pertembuhan anak. Perkembangan adalah bertambahnya sebuah kemampuan dari fungsi-fungsi organ tubuh, dari kemampuan gerak kasar, halus, pendengaran, cara komunikasi, penglihatan, sentuhan, emosi-sosial, dan lain-lain. Simulasi adalah merupakan sebuah perangsangan atau latihan - latihan terdapat kepandaian anak yang biasanya datang dari lingkungan luar anak, dan setiapanak perlu mendapatkan stimulasi secara rutin sedini mungkin dan dilakukan secara terus menerus bahkan menetap, dalam hal ini pengetahuan ibu juga mempengaruhi bagaimana cara ibu untuk menstimulus anaknya. (Anonim, 2013)

Demikian pula dengan skrining untuk mengetahui penyakit-penyakit potensial dapat mengakibatkan gangguan perkembangan anak karena deteksi dini kelainan perkembangan anak sangat berguna agar diagnosa maupun pemulihannnya dapat dilakukan lebih awal sehingga tumbuh kembang anak dapat berlangsung seoptimal mungkin. Penting untuk dipahami bahwa dengan skrining dan 


\section{BAGIMU NEGERI : JURNAL PENGABDIAN MASYARAKAT \\ P-ISSN : 2548-8651 | E-ISSN : 2548-866X \\ Email : ejournal@umpri.ac.id}

mengetahui adanya masalah pada perkembangan anak, tidak berarti bahwa diagnosa pasti dari kelalaian tersebut telah ditetapkan. Skrining hanyalah prosedur rutin dalam pemeriksaan tumbuh kembang anak sehari-hari, yang dapat memberikan petunjuk jika ada sesuatu yang perlu mendapat perhatian. Sehingga masih diperlukan anamnese yang baik, pemeriksaan fisik yang teliti dan pemeriksaan penunjang lainnya agar diagnosa dapat dibuat, supaya intervensi dan pengobatan dapat dilakukan sebaik-baiknya. Deteksi dini pada tumbuh kembang balita ini dapat dilakukan anamnesa dengan pemeriksaan fisik secara rutin, melakukan screening perkembangan dan pemeriksaan secara berkala dan berkelanjutan.

\section{METODE}

Kegiatan ini dilakukan dengan Perencanaan yaitu pertama melakukan konsolidasi bidan Desa Podomoro dan dengan beberapa kader untuk bekerja sama, kegiatan dibarengi dengan kegiatan posyandu balita di Desa Podomoro. Kedua persiapan Alat pengukur tinggi badan (microtoist) dan timbangan dapat disiapkan dengan baik. Ketiga menyiapkan kegiatan dengan tetap menerpakan protocol kesehatan, yaitu memakai masker, mencuci tangan dan menjaga jarak. Keempat melakukan skrining dengan lembar KPSP. Kelima memberikan edukasi kepada orangtua bayi dan balita mengenai pentingnya melakukan deteksi dini tumbuh kembang anak, memperhatikan segala aspek agar tumbuh kembang anaknya sesuai dengan usia. Keenam, dalam proses perencanaan tidak didapatkan kendala berarti, sesuai dengan yang diharapkan. Selajutnya adalah pelaksanaan yang dilakukan sesuai jadwal pada pukul 09.00 WIB dilakukan registrasi balita kemudian dilakukan pemeriksaan deteksi dini tentang pertumbuhan dan perkembangan balita. Setelah pemeriksaan balita kemudian dilakukan promosi kesehatan mengenai pertumbuhan dan perkembangan balita usia 2-54 bulan.

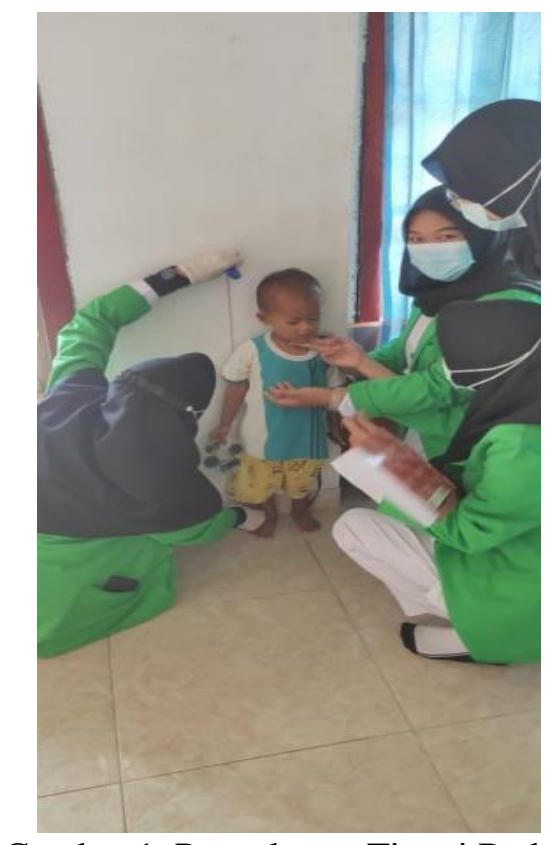

Gambar 1. Pengukuran Tinggi Badan 


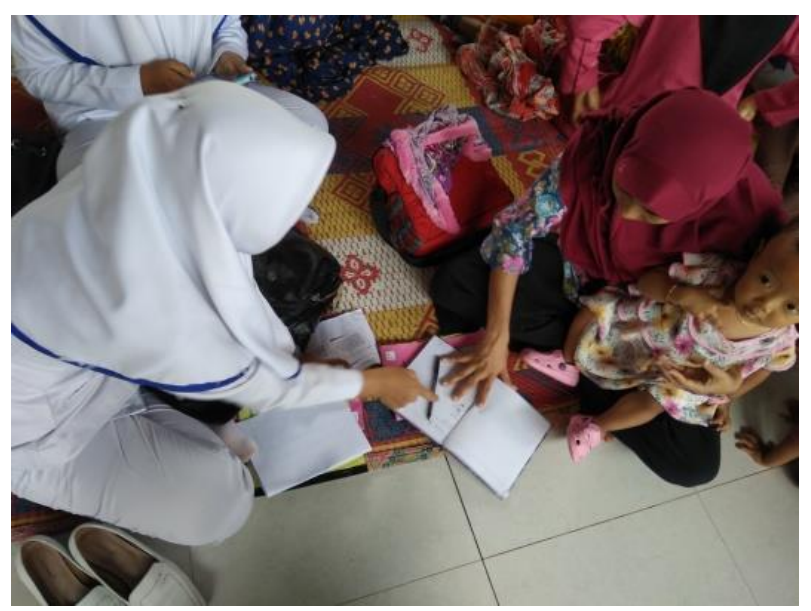

Gambar 2 Pengecekan Identitas dan Pengisian Hasil Pemeriksaan

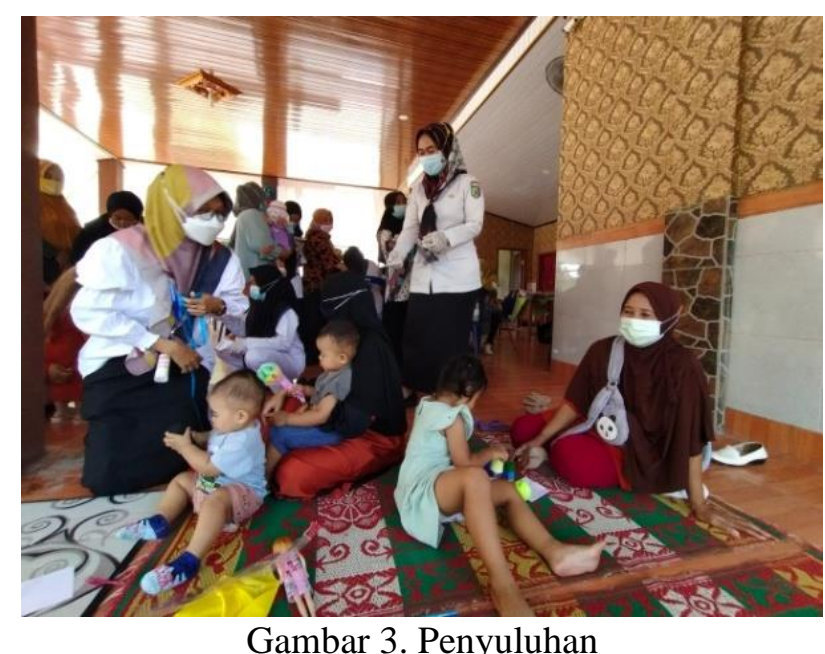

\section{HASIL DAN PEMBAHASAN}

Periode yang penting dalam tumbuh kembang pada anak ini adalah di saat usia dibawah lima tahun, hal ini mempengaruhi dan cukup menentukan perkembangan anak di tahap selanjutnya. (Soetjiningsih, 2013). Kegiatan pengabdian masyarakat ini mendapat respon positif terlihat dari antusiasme para orang tua saat dilakukan penyuluhan, diskusi, tanya jawab dan demonstrasi cara stimulasi tumbuh kembang anak. Stimulasi dini ini merupakan sebuah rangsangan yang dilakukan sejak berada dalam perut ibu (kandungan) yang dilakukan setiap hari guna merangsang perabaan, pembauan atau pun pengecapan. (Maryunani, 2015). Kegiatan ini berhasil memeriksa pertumbuhan dan perkembangan sebanyak 40 anak usia 1-5 yang terdiri dari 18 anak perempuan dan 12 anak laki-laki, 15 anak usia 3 tahun, 11 anak usia 4 tahun dan 7 anak usia 5 tahun.

Pemeriksaan pertumbuhan dilakukan dengan mengukur tinggi badan anak dan berat badan anak. Hasil pengukuran dikonversikan menurut kurva WHO dan diinterpretasikan menurut panduan WHO. Hasil deteksi dini penilaian pertumbuhan dengan kurva WHO didapatkan sebanyak 38 anak (92\%) perawakan normal dan gizi normal dan 2 anak (8\%) yaitu gizi kurang. Setelah itu dilakukan pemeriksaan dengan menggunakan kuesioner pra skrining perkembangan guna mendeteksi dini terdapat gangguan perkembangan pada anak. Dari hasil didapatkan sebanyak 35 anak (95\%) mengalami perkembangan

\section{I https://ejournal.umpri.ac.id/index.php/bagimunegeri}


sesuai dengan usia anak, dan 5 anak (5\%) dengan hasil meragukan, karena pada saat dilakukan tes anak tersebut ada yang mengantuk dan tidak kooperatif, maka disarankan untuk melakukan tes ulang dibulan depan, dan tidak terdapat anak yang mengalami pemyimpangan gangguan perkembangan. Edukasi orang tua pada anak gizi kurang yaitu memberikan anak asupan makanan sehari-hari yang mengandung zat-zat gizi dalam jumlah yang sesuai dengan jumlah kebutuhan tubuh, dengan memperhatikan prinsip, selain itu edukasi mengenai pentingnya stimulasi perkembangan bagi anak-anak usia 2 bulan-5 tahun, meliputi motorik kasar, motorik halus, perkembangan bahasa dan social. Materi disampaikan menggunakan powerpoint dengan media laptop, infocus dan contoh menu harian untuk anak prasekolah. Pada sesi ini beberapa ibu antusias bertanya dengan disertai kasus nyata yang terjadi sehari-hari.

Pembangunan kesehatan sebagai bagian dari upaya membangun manusia seutuhnya antara lain diselenggarakan melalui upaya kesehatan anak yang dilakukan sedini mungkin sejak masih didalam kandungan. Jumlah balita diindonesia sangat besar yaitu sekitar 10 persen dari seluruh populasi penduduk, maka kualitas tumbuh kembang balita perlu mendapatkan perhatian serius yaitu mendapat gizi yang baik, stimulasi yang memadai serta terjangkau oleh pelayanan kesehatan, termasuk deteksi dan intervensi dini pemyimpangan tumbuh kembang pada anak.

Salah satu upaya yang dapat dilakukan adalah dengan memberikan pendidikan pertumbuhan dan perkembangan kepada orang tua. Yang dimaksud dengan deteksi dini pertumbuhan adalah, mengukur berat badan dan tinggi badan anak sesuai dengan umur, sementara yang dimaksud dengan perkembangan adalah tahap perkembangannya pun sesuai dengan tahapan umurnya. Semisalnya pada anak usia 5 tahun sudah bisa lancar bicara, berlari. Selain pada jenis makanan, ibu dari balita juga diberikan penjelasan tentang bagaimana cara mengolah makanan dengan benar. Tujuan hal ini agar kandungan nutrisi di dalam makanan tetap terjaga dan terhindar dari kerusakan nutrisi. Contohnya sayur dan buah yang lebih mudah rusak harus di masak dengan waktu yang sebentar agar kandungan enzim di dalamnya tidak hilang.Pentingnya pendidikan nutrisi ini berguna untuk memfasilitasi ibu agar gizi balita yang mengalami gangguan dapat teratasi, dan balita mendapatkan makanan sesuai dengan proporsinya. Hal ini dilakukan sebagai upaya pencegahan kasus gangguan gizi lebih lanjut. Selain itu tenaga kesehatan dari layanan primer sebaiknya memberikan pendidikan nutrisi secara rutin melalui program posyandu atau kegiatan PKK bulanan untuk mendeteksi dini balita yang ada di wilayah kerjanya.

\section{SIMPULAN DAN SARAN}

Pelaksanaan kegiatan pengabdian masyarakat dengan tema deteksi dini gangguan pertumbuhan dan perkembangan serta edukasi kepada orangtua berlangsung lancar, penuh antusiasme anak maupun ibu atau orang tua. Kegiatan ini berhasil melakukan deteksi pada 40 anak. Deteksi dini penilaian pertumbuhan dengan kurva WHO didapatkan sebanyak 38 anak (92\%) perawakan normal dan gizi normal dan 2 anak (8\%) yaitu gizi kurang. Untuk pemeriksaan perkembangan anak dengan instrument KPSP didapatkan hasil sebanyak 35 anak (95\%), dengan perkembangan sesuai. dan 5 anak (5\%) dengan perkembangan meragukan. Deteksi dini tumbuh kembang anak diperlukan untuk pengenalan awal gangguan dan intervensi dini sehingga pertumbuhan dan perkembangan anak optimal. Hal ini memerlukan pengetahuan, kesadaran, komitmen dan tindakan nyata orangtua masing-masing anak agar tercapai tumbuh kembang yang optimal selain dari peran tenaga kesehatan. 


\section{DAFTAR PUSTAKA}

Dewi, V. (2010). Asuhan Neonatus Bayi dan Anak Balita. Jakarta. Salemba Medika.

Paparan RISKESDA (2013). Diunduh dari http//:www.labdata.litbang.depkes.go.id.

Anonim. (2013). Masa Emas Perkembangan Otak. www.google.com.

http://www.tigaraksaeducationalproducts.com/page/articles/mengawali-masa-emasperkembangan-otak-si-kecil.

Depkes, R. I. (2012). Upaya Percepatan Penurunan Angka Kematian Ibu dan Bayi Baru Lahir. http://www.gizikia.depkes.go.id/artikel/upaya-percepatanpenurunan-angka-kematian-ibu-danbayi-baru-lahir-di-indonesial.

Hidayat, A. A. (2009). Pengantar Kebutuhan Dasar Manusia : Aplikasi Konsep dan Proses Keperawatan. Salemba Medika.

Maryunani, A. (2015). Ilmu kesehatan anak. Info Media.

Soetjiningsih, I. N. G. R. (2013). Tumbuh Kembang Anak Edisi 2. Penerbit Buku Kedokteran (EGC).

Setyaningsih,Pujiati, \& Khanifah, Milatun \& Chabibah, Nur. (2017). Layanan Tumbuh Kembang Balita dengan Pendampingan Ibu dan Anak Sehat. Jurnal University Research Colloquium. 8186

Simanjuntak, Charles Apul; Fitri, Amelia Dwi; Ayu, Natasha; Puspasari, Anggelia. (2013). Deteksi Dini Dana Edukasi Orang Tua Tentang Gangguan Tumbuh Kembang Balita. Jurnal Karya Abdi Masyarakat. 